\title{
SPECTROPHOTOMETRIC STUDY OF THE INTERACTION OF PLATINUM(IV) WITH NEW DERIVATIVES OF AZOLIDONES
}

\author{
Oleksandr Tymoshuk ${ }^{1}$, Lesia Oleksivi, ${ }^{凶}$, Petro Rydchuk ${ }^{1}$, Taras Chaban $^{2}$, \\ Svitlana Tymoshuk ${ }^{1}$, Vasyl Matiychuk ${ }^{1}$
}

https://doi.org/10.23939/chcht14.02.139

\begin{abstract}
The interaction of $\mathrm{Pt}(\mathrm{IV})$ ions with the new derivatives of azolidones by spectrophotometric method was investigated. The spectrophotometric method for the determination of $\mathrm{Pt}(\mathrm{IV})$ using 5-hydroxyimino-4-imino-1,3thiazolidine-2-one at $\mathrm{pH} 5.0$ in acetate buffer medium was elaborated. The proposed method was tested by determination of Pt(IV) in model solutions and metallic alloy.
\end{abstract}

Keywords: spectrophotometry, platinum(IV), azolidones, complex.

\section{Introduction}

Platinum and its alloys attract considerable attention due to valuable physical, chemical and mechanical properties. Platinum and its compounds have wide practical application in various industries, including: chemical, jewelry, metallurgical, pharmaceutical, medical, electroand radioengineering, and others $[1,2]$. If platinum is added to alloy its catalytic properties are improved. Alloys of platinum with cobalt are characterized by strong ferromagnetic properties [3]. Platinum catalysts are also widely used in the automotive industry [4]. Therefore, it is important to control the content of platinum in industrial and natural objects, which requires the development of new simple and reliable methods for this metal determination as the main component or admixture in various materials.

Different highly sensitive methods are used for the platinum determination, in particular: atomic absorption spectroscopy, inductively coupled plasma mass spectrometry, neutron activation analysis, and others [4]. However, the use of these methods is limited by the high cost of the equipment and most of them require prior separation and concentration to avoid matrix interference and increase sensitivity. Therefore, spectrophotometric methods, which provide high sensitivity due to the

\footnotetext{
${ }^{1}$ Ivan Franko National University of Lviv,

6, Kyryla and Mefodiya St., 79005 Lviv, Ukraine

${ }^{2}$ Danylo Halytsky Lviv National Medical University, 69, Pekarska St., 79010 Lviv, Ukraine

¿_lozynska@ukr.net

(C) Tymoshuk O., Oleksiv L., Rydchuk P., Chaban T., Tymoshuk S., Matiychuk V., 2020
}

application of specific and sensitive organic reagents, are often used as an alternative. It is known from literature that rhodanine derivatives are among the reagents for platinum determination $[1,5-8]$. Some examples of these reagents used for the determination of platinum are given in Table 1.

Most of the reactions are long-lasting and the interaction takes place in a strongly acidic medium. Also, these techniques are not suitable for objects with low content of platinum and a significant siliceous matrix (ceramic silicate catalysts, silicate ores, field transistors, etc.). Conducting an analysis according to the proposed methods is either impossible or involves considerable difficulty in sample preparation. Therefore, the aim of our work was to develop simple, sensitive, selective, expressive and accessible methods for platinum determination using the new organic reagents that would be suitable for the analysis of such objects in non-acidic media (in order to carry out the determination in the presence of silicate ions, REM and other interfering ions without prior separation). In our previous work we demonstrated an important role of azoheterocycles in organic [9-12] and analytical chemistry [13-24]. In particular the new spectrophotometric methods, with good analytical characteristics, for the determination of $\operatorname{Pd}(\mathrm{II})$, $\mathrm{Rh}(\mathrm{III}), \mathrm{Ir}(\mathrm{IV}), \mathrm{Ru}(\mathrm{IV}), \mathrm{Cu}(\mathrm{II}), \mathrm{Zn}(\mathrm{II}), \mathrm{Cd}(\mathrm{II}), \mathrm{Hg}(\mathrm{II})$, and $\mathrm{Ni}(\mathrm{II})$ by using azolidone derivatives were developed [13-25].

Therefore, in our work, we have investigated the interaction of $\mathrm{Pt}(\mathrm{IV})$ ions with the new analytical reagents that are analogs of rhodanine and belong to the class of azolidones - 4-[2-(3-metyl-5-oxo-1-phenyl-1,5-dihydro$4 H$-pyrazol-4-ylidene)-hydrazino]-benzensylfonat sodium (PHBS), 5-hydroxyimino-4-imino-1,3-thiazolidin-2-one (HITO) and 4-[N'-(4-imino-2-oxo-thiazolidin-5-ylidene)hydrazino]-benzenesulfonic acid (ITHBA), which were previously investigated as reagents for other platinum metals (Pd(II), Rh(III), Ir(IV), and Ru(IV)) [13-15, 17]. The research is of considerable relevance since a significant number of azolidone derivatives and their complexes with platinum metals are potential anti-cancer agents [26]. 
Use of rhodanine derivatives for spectrophotometric determination of platinum

\begin{tabular}{|c|c|c|c|}
\hline Reagent & Metal & Conditions & Ref. \\
\hline Sulfochlorophenolazorhodanine & $\operatorname{Pt}(\mathrm{IV})$ & $\begin{array}{l}3 \mathrm{M} \mathrm{HCl}, 4 \mathrm{~h}, \lambda=500 \mathrm{~nm} ; \\
2 \mathrm{M} \mathrm{HCl}+2 \mathrm{M} \mathrm{H}_{3} \mathrm{PO}_{4} \text {, ascorbic acid, } 4 \mathrm{~h}, \lambda=500 \mathrm{~nm}\end{array}$ & {$[1],[5],[6]$} \\
\hline Sulfochlorophenolazorhodanine & $\mathrm{Pt}(\mathrm{II})$ & $\begin{array}{l}3 \mathrm{M} \mathrm{HCl}+\text { ascorbic acid, } 20 \mathrm{~h}(293 \mathrm{~K}), \lambda=500 \mathrm{~nm} ; \\
2 \mathrm{M} \mathrm{HCl}+2 \mathrm{M} \mathrm{H}_{3} \mathrm{PO}_{4}+\text { ascorbic acid, } 4 \mathrm{~h}(293 \mathrm{~K}), \lambda=500 \mathrm{~nm}\end{array}$ & {$[1],[5],[7]$} \\
\hline $\begin{array}{l}\text { Sulfochlorophenolazothiopro- } \\
\text { piorhodanine (tyrodine) }\end{array}$ & $\operatorname{Pt}(\mathrm{II})$ & $7.6 \mathrm{M} \mathrm{H}_{3} \mathrm{PO}_{4}, 3 \mathrm{~h}, \lambda=510 \mathrm{~nm}$ & {$[6],[7]$} \\
\hline $\begin{array}{l}\text { Sulfochlorophenolazothiopro- } \\
\text { piorhodanine (tyrodine) }\end{array}$ & $\mathrm{Pt}(\mathrm{IV})$ & 7.6 $\mathrm{M} \mathrm{H}_{3} \mathrm{PO}_{4}+$ ascorbic acid $3-4 \mathrm{~h}, \lambda=510 \mathrm{~nm}$ & {$[1]$} \\
\hline$m$-Sulfobenzeneazorhodanine & $\mathrm{Pt}(\mathrm{IV})$ & $2 \mathrm{M} \mathrm{H}_{3} \mathrm{PO}_{4}, 15 \min (353 \mathrm{~K}), \lambda=520 \mathrm{~nm}$ & [5], [8] \\
\hline
\end{tabular}<smiles>CC1=NN(c2ccccc2)C(=O)/C1=N/Nc1ccc(S(=O)(=O)O[Na])cc1</smiles>

a)<smiles>N=C1NC(=O)S/C1=N/O</smiles>

b)<smiles>N=C1NC(=O)S/C1=N/Nc1ccc(S(=O)(=O)O)cc1</smiles>

c)

Fig. 1. Structural formulas of PHBS (a), HITO (b) and ITHBA (c)

PHBS is an orange powder, well soluble in water; HITO is a crystalline sand-colored powder, poorly soluble in water $\left(0.05 \mathrm{~g} \cdot \mathrm{l}^{-1}\right)$, but well soluble in a number of organic solvents: ethanol, methanol, $n$-propanol, isoamyl alcohol, ethylene glycol, glycerol, dimethylformamide, and dimethyl sulfoxide. ITHBA is a yellow powder, well soluble in water. Structural formulas of these reagents are shown in Fig. 1.

\section{Experimental}

\subsection{Reagents}

A stock solution of $\mathrm{Pt}(\mathrm{IV})$ was prepared by dissolving the metallic platinum $(99.999 \%)$ in a mixture of concentrated nitric and hydrochloric acids (1:3) by heating on a sand bath. The standard working solution of $\mathrm{Pt}(\mathrm{IV})$ was prepared by diluting an aliquot of platinum(IV) stock solution in $1.0 \mathrm{~mol} \cdot \mathrm{l}^{-1} \mathrm{HCl}$.

The stock solutions of 4-[2-(3-metyl-5-oxo-1phenyl-1,5-dihydro- $4 H$-pyrazol-4-ylidene)-hydrazino]benzensylfonat sodium and 4-[ $N$-(4-imino-2-oxothiazolidin-5-ylidene)-hydrazino]-benzenesulfonic acid were prepared by dissolving the appropriate amounts of pre-purified reagents in distilled water.

A stock solution of 5-hydroxyimino-4-imino-1,3thiazolidin-2-one was prepared by dissolving the appropriate amount of pre-purified reagent in $96 \% \mathrm{v} / \mathrm{v}$ ethanol.
Solutions of $\mathrm{NaCl}, \mathrm{CH}_{3} \mathrm{COONa}, \mathrm{NaOH}$, and other solutions of sodium salts (an anionic effect of which was investigated) were prepared by dissolving the respective salts in distillated water. The solutions of $\mathrm{HCl}$ and $\mathrm{CH}_{3} \mathrm{COOH}$ were prepared by dilution of the corresponding concentrated acids. The standard solutions of different metals (which were used during the study of the selectivity) were prepared by dissolving the exact mass of the corresponding metal in hydrochloric or nitric acids, their mixture, or their salts in distilled water or in dilute $\mathrm{HCl}$ or $\mathrm{HNO}_{3}$. The solution of $\mathrm{Ru}(\mathrm{IV})$ was prepared by sintering of metal with the oxidizing mixture $\mathrm{NaNO}_{3}+\mathrm{NaOH}(1: 3)$ with further dissolving the fusion in $3.0 \mathrm{~mol} \cdot \mathrm{l}^{-1} \mathrm{HCl}$. The solutions of $\mathrm{Ir}(\mathrm{IV})$ and $\mathrm{Rh}(\mathrm{III})$ were prepared by sintering corresponding metal with the oxidizing mixture $\mathrm{NaNO}_{3}+\mathrm{NaOH}(1: 3)$ and $\mathrm{BaO}_{2}$ with further dissolving the fusion in $3.0 \mathrm{~mol} \cdot \mathrm{l}^{-1}$ of hydrochloric acid.

\subsection{Equipment}

Spectrophotometric measurements were performed using ULAB 108UV computerized spectrophotometer and $1.0 \mathrm{~cm}$ quartz cells.

Voltammetric measurements were carried out using an oscillopolarograph CLA-03 and computerized polagraphic setup with linear potential scan in three-electrode cell. A dropping mercury electrode was an indicator electrode, saturated calomel electrode - reference electrode and platinum electrode - auxiliary electrode. 
The $\mathrm{pH}$-meter model $\mathrm{pH}-150 \mathrm{M}$ equipped with a combination glass electrode was used for $\mathrm{pH}$ measurements.

\subsection{Procedure for Determination of Pt(IV) using HITO}

An aliquot of the test solution containing $\operatorname{Pt}(\mathrm{IV})$ within $\left(7.0 \cdot 10^{-6}\right)-\left(8.0 \cdot 10^{-5}\right) \mathrm{mol} \cdot \mathrm{l}^{-1}$ in the final volume, $0.25 \mathrm{ml}$ of $8.0 \cdot 10^{-3} \mathrm{~mol} \cdot \mathrm{l}^{-1}$ etanolic solution of $5-$ hydroxyimino-4-imino-1,3-thiazolidine-2-one, $1.25 \mathrm{ml}$ of $2.0 \mathrm{~mol} \cdot \mathrm{l}^{-1}$ solution of sodium chloride, $2.0 \mathrm{ml}$ of $4.0 \mathrm{~mol} \cdot \mathrm{l}^{-1}$ sodium acetate solution, and distilled water $(\sim 15 \mathrm{ml})$ were added in a volumetric $25.0 \mathrm{ml}$ flask. The acidity of the solution obtained was checked at $\mathrm{pH}$-meter, the $\mathrm{pH}$ value was adjusted to 5.0 by acetate acid or sodium acetate and distilled water was added to complete the volume. Measurement of the absorbance of the investigated solution was carried out after $60 \mathrm{~min}$ of heating of solutions in a boiling water bath $(\sim 371 \mathrm{~K})$ and cooling to room temperature $(\sim 291-296 \mathrm{~K})$ at the wavelength $\lambda=350 \mathrm{~nm}$ on a spectrophotometer using cuvettes with $l=1.0 \mathrm{~cm}$ against blank solution.

\subsection{Procedure for Determination of Pt(IV) in the Alloy}

Alloys weighing about $0.07 \mathrm{~g}$ were dissolved in 10-20 $\mathrm{ml}$ of concentrated chloride and nitric acid (3:1). The mixture was boiled in a sand bath for several hours. The solution was quantitatively transferred into a $50.0 \mathrm{ml}$ volumetric flask and brought to the mark with $2.5 \mathrm{M} \mathrm{HCl}$. The working solution was prepared by diluting stock solution 10 times with $1.0 \mathrm{~mol} \cdot \mathrm{l}^{-1} \mathrm{HCl}$. For the analysis aliquots of 1.0-2.0 $\mathrm{ml}$ were taken. The determination of

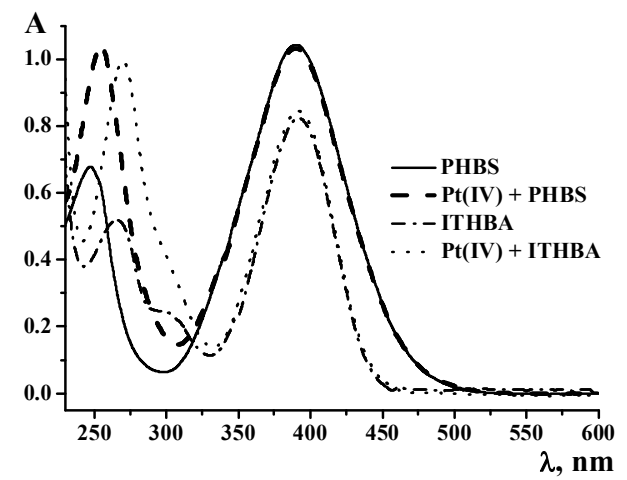

Fig. 2. Absorption spectra of PHBS, ITHBA and Pt(IV) with the reagents (PHBS: $C_{\mathrm{Pt}(\mathrm{IV})}=2.0 \cdot 10^{-5} \mathrm{~mol} \cdot 1^{-1}$; $C_{\mathrm{PHBS}}=4.0 \cdot 10^{-5} \mathrm{~mol} \cdot \mathrm{l}^{-1} ; C_{\mathrm{NaCl}}=0.1 \mathrm{~mol} \cdot 1^{-1} ; \mathrm{pH}=5.0$; $l=1.0 \mathrm{~cm}$; ITHBA: $C_{\mathrm{Pt}(\mathrm{IV})}=2.0 \cdot 10^{-5} \mathrm{~mol} \cdot \mathrm{l}^{-1}$; $C_{\text {ITHBA }}=4.0 \cdot 10^{-5} \mathrm{~mol} \cdot 1^{-1} ; C_{\mathrm{NaCl}}=0.1 \mathrm{~mol} \cdot 1^{-1}$; $\mathrm{pH}=8.0 ; l=1.0 \mathrm{~cm})$
Pt(IV) in the alloy was carried out according to the procedure described in Subsection 2.3. The concentration of Pt(IV) was found using the pre-built calibration curve or comparison method.

\section{Results and Discussion}

\subsection{Investigation of $\mathrm{Pt}(\mathrm{IV})$ Interaction with PHBS, HITO and ITHBA}

Our previous researches of the spectral and protolytic characteristics of the PHBS, HITO and ITHBA $[13,15,16]$ shown that these reagents are characterized by high values of molar absorption coefficients, which are in the range of $\left(1.02 \cdot 10^{4}\right)-\left(2.53 \cdot 10^{4}\right) 1 \cdot \mathrm{mol}^{-1} \cdot \mathrm{cm}^{-1}$. The greatest values were found for ITHBA and PHBS $\left(2.53 \cdot 10^{4} 1 \cdot \mathrm{mol}^{-1} \cdot \mathrm{cm}^{-1}\right.$ and $2.50 \cdot 10^{4} 1 \cdot \mathrm{mol}^{-1} \cdot \mathrm{cm}^{-1}$, respectively) at 382 and $390 \mathrm{~nm}$. Concentration constants of acidity were determined: for HITO $p K_{\mathrm{a}}=7.1$ and for ITHBA $p K_{\mathrm{a}}=10.0$. The investigated azolidones do not form tautomers in the concentration range from $10^{-5}$ to $10^{-4} \mathrm{~mol} \cdot \mathrm{l}^{-1}$. It was found that HITO is unstable with time in the range of $\mathrm{pH}=6.0-12.0$, and ITHBA is unstable within $\mathrm{pH}=10.0-12.0$.

It was investigated that in the presence of $\mathrm{Pt}(\mathrm{IV})$ ions, the absorption spectra of PHBS in the $\mathrm{pH}$ range of $1.0-12.0$ are characterized by some increase in absorption maximum at $\lambda=250 \mathrm{~nm}$, but no changes occur in the visible region of the spectrum of the reagent itself. A similar situation was observed during the interaction of Pt(IV) with ITHBA, which means that using PHBS or ITHBA for spectrophotometric determination of platinum is inappropriate (Fig. 2).

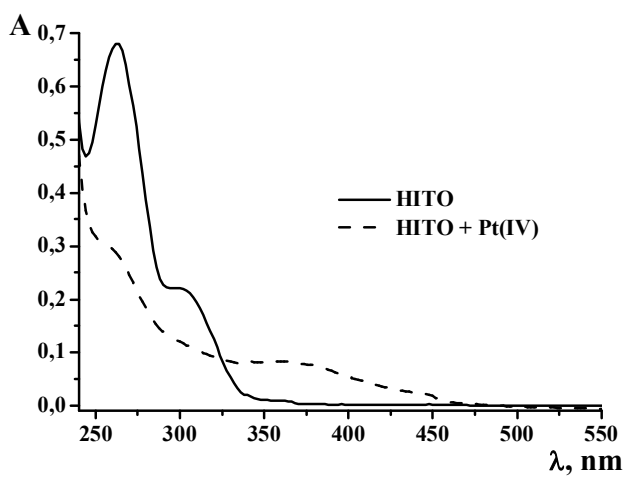

Fig. 3. Absorption spectra of HITO and complex Pt(IV) with HITO $\left(C_{\mathrm{Pt}(\mathrm{IV})}=2.0 \cdot 10^{-5} \mathrm{~mol} \cdot \mathrm{l}^{-1}\right.$; $C_{\mathrm{HITO}}=4.0 \cdot 10^{-5} \mathrm{~mol} \cdot 1^{-1} ; C_{\mathrm{NaCl}}=0.1 \mathrm{~mol} \cdot \cdot^{-1}$; $\mathrm{pH}=5.0 ; l=1.0 \mathrm{~cm})$ 
HITO interacts with $\mathrm{Pt}(\mathrm{IV})$ ions to form a complex $[18,19]$. The electronic absorption spectra of the resulting complex and reagent are shown in Fig. 3.

\subsubsection{The optimal conditions of the Pt(IV)-HITO complex formation}

In the presence of Pt(IV) ions the maximum of HITO at $264 \mathrm{~nm}$ decreases and a shoulder of absorption in the wavelengths range of $325-450 \mathrm{~nm}$ is observed. The maximum difference in absorption of the reagent and the $\mathrm{Pt}(\mathrm{IV})-\mathrm{HITO}$ complex is observed at $350 \mathrm{~nm}$ (Fig. 3), therefore, all further studies were conducted at this wavelength. The complex compound Pt(IV)-HITO is formed in wide limits of the medium acidity, and the maximum yield is observed at $\mathrm{pH}=5.0-6.0$ (Fig. 4). However, since HITO is unstable in the range of $\mathrm{pH}=$ $=6.0-12.0$, no research was conducted for the effect of $\mathrm{pH}$ on the formation of the Pt(IV) complex from HITO within these limits of the acidity of the medium.

The impact of the nature of the anions and the ionic strength on the interaction of Pt(IV) with HITO in the presence of various sodium salts was studied. Anions $\left(\mathrm{Cl}^{-}\right.$,

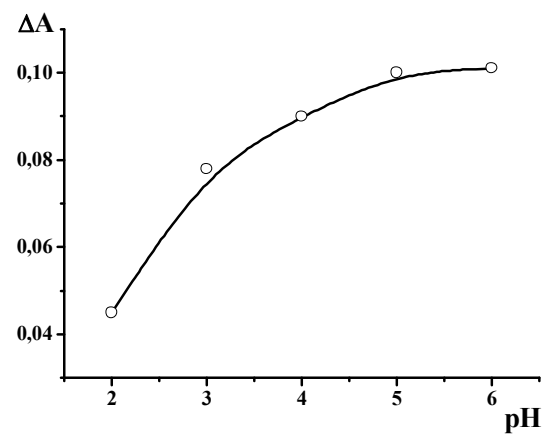

Fig. 4. Effect of $\mathrm{pH}$ on the $\mathrm{Pt}(\mathrm{IV})-\mathrm{HITO}$ complex formation $\left(C_{\mathrm{Pt}(\mathrm{IV})}=2.0 \cdot 10^{-5} \mathrm{~mol} \cdot 1^{-1} ; C_{\mathrm{HITO}}=4.0 \cdot 10^{-5} \mathrm{~mol} \cdot \cdot^{-1} ; C_{\mathrm{NaCl}}=\right.$ $\left.0.1 \mathrm{~mol} \cdot 1^{-1} ; \mathrm{pH}=5.0 ; l=1.0 \mathrm{~cm} ; \lambda=350 \mathrm{~nm}\right)$

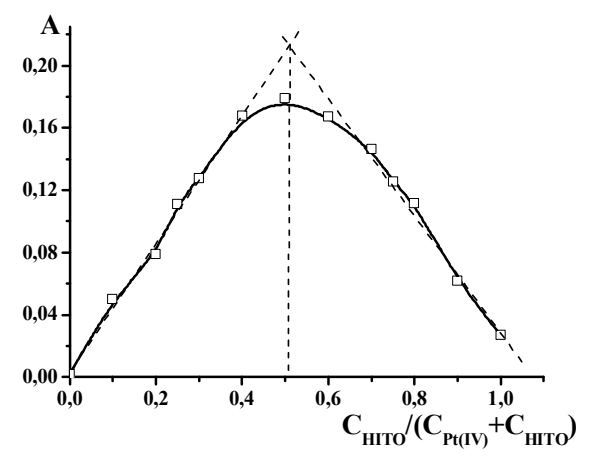

Fig. 6. The continuous variation curve for $\mathrm{Pt}(\mathrm{IV})-\mathrm{HITO}$ complex $\left(C_{\mathrm{Pt}(\mathrm{IV})+\mathrm{HITO}}=1.0 \cdot 10^{-4} \mathrm{~mol} \cdot 1^{-1} ; C_{\mathrm{NaCl}}=0.1 \mathrm{~mol} \cdot 1^{-1}\right.$; $C_{\mathrm{CH} 3 \mathrm{COOH}+\mathrm{CH} 3 \mathrm{COONa}}=0.32 \mathrm{~mol} \cdot \mathrm{l}^{-1} ; \mathrm{pH}=5.0 ; l=1.0 \mathrm{~cm}$; $\left.\lambda=350 \mathrm{~nm} ; t_{\text {heat. }}=60 \mathrm{~min}(\sim 371 \mathrm{~K})\right)$
$\left.\mathrm{NO}_{3}^{-}, \mathrm{SO}_{4}{ }^{2-}, \mathrm{ClO}_{4}^{-}, \mathrm{CH}_{3} \mathrm{COO}^{-}\right)$practically do not effect the formation of the Pt(IV)-HITO complex. To create a constant ionic strength and stable $\mathrm{pH}$ the acetate buffer solution $(0.32 \mathrm{M})$ and sodium chloride $(0.1 \mathrm{M})$ were used as the reaction medium.

The complex formation of $\mathrm{Pt}(\mathrm{IV})$ with HITO occurs quite slowly at room temperature ( 291-295 K). Since the kinetic inertness of the halide complexes of platinum metals can be overcome by heating, in the case of HITO, the formation of a colored complex compound $\mathrm{Pt}(\mathrm{IV})$ with HITO was studied under heating in a boiling water bath ( $\sim 371 \mathrm{~K}$, Fig. 5). Maximum values of absorbance for Pt(IV)-HITO compound without heating are achieved after $24 \mathrm{~h}$, and when heated in a boiling water bath - after $60 \mathrm{~min}$. Therefore, further research was carried out after $60 \mathrm{~min}$ of heating of solutions in a boiling water bath. The values of absorbance of the solution of complex obtained after heating remain stable for $8-10 \mathrm{~h}$.

The ratio of components in the complex compound of Pt(IV) with HITO was determined by methods of continuous variations and mole-ratio (Figs. 6 and 7).

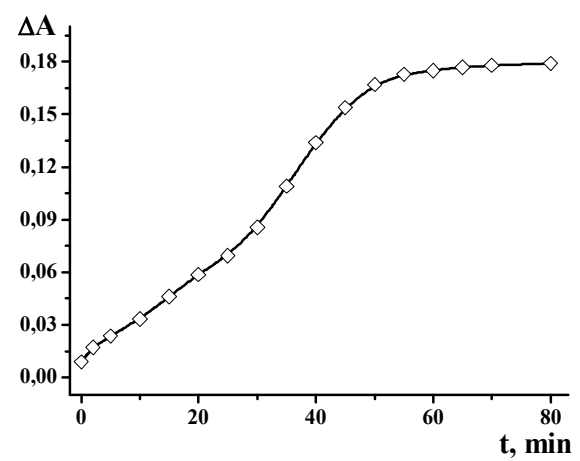

Fig. 5. Effect of heating time on the Pt(IV)-HITO complex formation $\left(C_{\mathrm{Pt}(\mathrm{IV})}=2.0 \cdot 10^{-5} \mathrm{~mol} \cdot \mathrm{l}^{-1} ; C_{\mathrm{HITO}}=4.0 \cdot 10^{-5} \mathrm{~mol} \cdot \mathrm{l}^{-1}\right.$; $C_{\mathrm{NaCl}}=0.1 \mathrm{~mol} \cdot 1^{-1} ; C_{\mathrm{CH} 3 \mathrm{COOH}+\mathrm{CH} 3 \mathrm{COONa}}=0.32 \mathrm{~mol} \cdot \cdot^{-1} ; \mathrm{pH}=5.0$; $l=1.0 \mathrm{~cm} ; \lambda=350 \mathrm{~nm})$

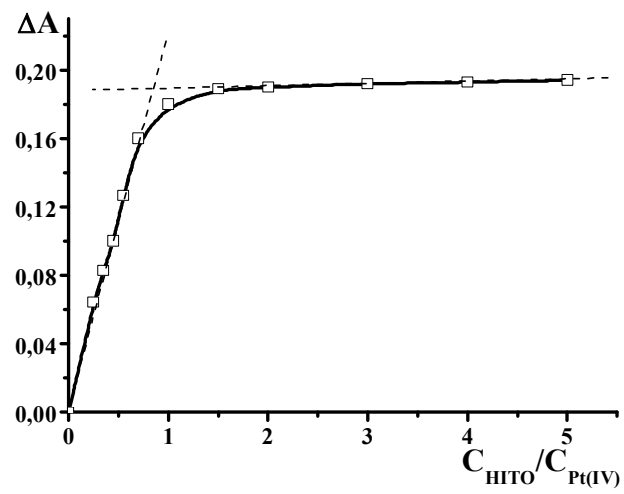

Fig. 7. The mole-ratio method for determination of the composition of the $\mathrm{Pt}(\mathrm{IV})-\mathrm{HITO}$ complex $\left(C_{\mathrm{Pt}(\mathrm{IV})}=5.0 \cdot 10^{-5} \mathrm{~mol} \cdot \mathrm{l}^{-1}\right.$; $C_{\mathrm{NaCl}}=0.1 \mathrm{~mol} \cdot 1^{-1} ; C_{\mathrm{CH} 3 \mathrm{COOH}+\mathrm{CH} 3 \mathrm{COONa}}=0.32 \mathrm{~mol} \cdot 1^{-1} ; \mathrm{pH}=5.0$; $\left.l=1.0 \mathrm{~cm} ; \lambda=350 \mathrm{~nm} ; t_{\text {heat. }}=60 \min (\sim 371 \mathrm{~K})\right)$ 
As can be seen from Fig. 7, for maximum yield of the complex compound Pt(IV) with HITO 1-1.5-fold excess of the reagent is optimal.

The obtained results indicate the formation of a complex with the ratio of components $\mathrm{Pt}(\mathrm{IV}): \mathrm{HITO}=1: 1$. The value of effective molar absorption coefficient at $350 \mathrm{~nm}$ is $5.54 \cdot 10^{3} 1 \cdot \mathrm{mol}^{-1} \cdot \mathrm{cm}^{-1}$. Since the calculation of the stability constant for the platinum complexes is rather complicated due to the long time of the equilibrium processes, it is possible to calculate the complex formal stability constant, equal to $\lg K^{f}=5.8$.

\subsubsection{Voltammetric investigation of the interaction of $\mathrm{Pt}(\mathrm{IV})$ with HITO}

In order to confirm the complex formation between ions of $\mathrm{Pt}(\mathrm{IV})$ and HITO, a voltammetric method, namely, oscillovoltammetry, was used additionally (Fig. 8).

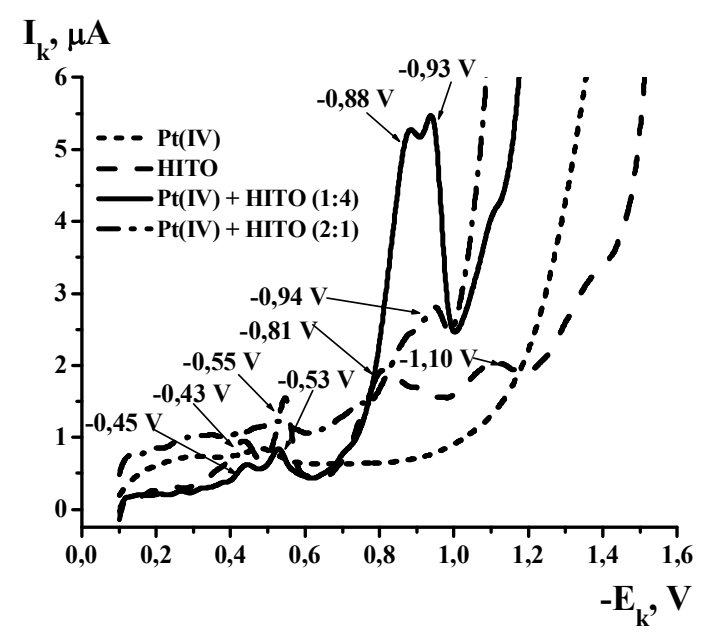

Fig. 8. Voltammograms of reduction Pt(IV) and HITO in the presence and in the absence of $\mathrm{Pt}(\mathrm{IV})$ ions

$$
\begin{gathered}
\left(C_{\mathrm{HITO}}=8.0 \cdot 10^{-5} \mathrm{~mol} \cdot 1^{-1} ; C_{\mathrm{NaCl}}=0.1 \mathrm{~mol} \cdot 1^{-1} ;\right. \\
C_{\mathrm{CH} 3 \mathrm{COOH}+\mathrm{CH} 3 \mathrm{COONa}}=0.32 \mathrm{~mol} \cdot 1^{-1} ; \mathrm{pH}=5.0 ; \\
\left.t_{\text {heat. }}=60 \mathrm{~min}(\sim 371 \mathrm{~K}) ; V=1.0 \mathrm{~V} / \mathrm{s}\right)
\end{gathered}
$$

The voltammograms of the reduction of $\mathrm{Pt}(\mathrm{IV})$, HITO and the compound Pt(IV)-HITO (Fig. 8) indicate that as a result of the interaction of platinum with HITO a complex is formed. With excess reagent in relation to the metal, there is a decrease in the reduction peaks of the reagent itself, as well as their displacement. In the presence of HITO the restoration of platinum from the complex is facilitated, and later the ligand itself is reduced on the platinum. In this case, we can talk about the catalysis of the ligand.

\subsection{Metrological Characteristics of the Developed Method}

It is established that the magnitude of the analytical signal of the complex of Pt(IV) with HITO linearly depends on the concentration of platinum in the solution. Metrological characteristics of the spectrophotometric determination of $\mathrm{Pt}(\mathrm{IV})$ with 5-hydroxyimino-4-imino1,3-thiazolidine-2-one are given in Table 2. The developed method is characterized by wide linear range and is sufficiently sensitive.

\subsection{Investigation of the Foreign Ions Effect}

The effect of various foreign ions, that are often found in platinum-containing objects, on the spectrophotometric determination of $\mathrm{Pt}(\mathrm{IV})$ using HITO was researched (Table 3) $[18,19]$. The results presented in Table 3 show that the determination of Pt(IV) using HITO is not interfered with the significant excesses of $\mathrm{Co}$ (II), $\mathrm{Ni}(\mathrm{II}), \mathrm{Mn}(\mathrm{II}), \mathrm{Zn}(\mathrm{II}), \mathrm{Cd}(\mathrm{II}), \mathrm{Pb}(\mathrm{II}), \mathrm{Yb}(\mathrm{III}), \mathrm{Tb}(\mathrm{III})$, $\mathrm{Ho}(\mathrm{III}), \mathrm{Gd}(\mathrm{III}), \mathrm{Ca}(\mathrm{II}), \mathrm{Mg}(\mathrm{II})$, and $\mathrm{Ba}(\mathrm{II})$. The investigated anions do not interfere with large excesses, therefore some of them were used as masking agents to eliminate the interfering effects of certain cations (Table 4). Due to this, it was possible to increase the selectivity of the developed method for such cations as $\mathrm{Ru}(\mathrm{IV}), \mathrm{Cu}(\mathrm{II})$, $\mathrm{Fe}(\mathrm{III})$, and $\mathrm{Al}(\mathrm{III})$.

\subsection{Application of the Developed Method}

The precision and accuracy of the spectrophotometric determination of $\mathrm{Pt}(\mathrm{IV})$ with HITO was studied by analyzing the model solutions using the "added-found" method. The results are shown in Table 5.

Table 2

\section{Metrological characteristics}

of spectrophotometric determination of $\operatorname{Pt}(\mathrm{IV})$ with HITO

\begin{tabular}{|c|c|c|c|}
\hline $\begin{array}{c}\text { Linear range, } \\
C_{\mathrm{Pt}(\mathrm{IV})}, \mathrm{mol}^{-1} \mathrm{l}^{-1}\end{array}$ & $\begin{array}{c}\text { Equation of the calibration curve, } \\
C_{\mathrm{Pt}(\mathrm{IV})}, \mathrm{mol}^{-1} \mathrm{l}^{-1}\end{array}$ & $\begin{array}{c}\text { Limit of detection, } \\
\mathrm{mol}^{-1} \mathrm{l}^{-1}\end{array}$ & $\begin{array}{c}\text { Correlation } \\
\text { coefficient, } R\end{array}$ \\
\hline $7.0 \cdot 10^{-6}-8.0 \cdot 10^{-5}$ & $\Delta \mathrm{A}_{350}=(0.014 \pm 0.004)+(5.79 \pm 0.09) \cdot 10^{3} \cdot \mathrm{C}_{\mathrm{P}(\mathrm{IV})}$ & $2.4 \cdot 10^{-6}$ & 0.9995 \\
\hline
\end{tabular}

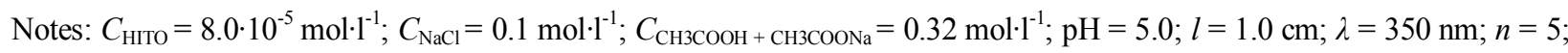
$P=0.95$
} 
Selectivity of spectrophotometric determination of $\operatorname{Pt}(\mathrm{IV})$ with HITO

\begin{tabular}{|c|c|c|c|c|c|}
\hline Ion & $C_{\mathrm{Pt}(\mathrm{IV})}: C_{\text {ion }}$ & Ion & $C_{\mathrm{Pt}(\mathrm{IV})}: C_{\text {ion }}$ & Ion & $C_{\mathrm{Pt}(\mathrm{IV})}: C_{\text {ion }}$ \\
\hline $\mathrm{Pd}(\mathrm{II})$ & $1: 0.15$ & $\mathrm{Ga}(\mathrm{III})$ & $1: 10$ & $\mathrm{Fe}(\mathrm{III})$ & $1: 0.1$ \\
\hline $\mathrm{Rh}(\mathrm{III})$ & $1: 0.1$ & $\mathrm{Sn}(\mathrm{II})$ & $1: 3$ & $\mathrm{Cu}(\mathrm{II})$ & $1: 0.1$ \\
\hline $\operatorname{Ir}(\mathrm{IV})$ & $1: 0.2$ & $\mathrm{Ce}(\mathrm{IV})$ & $1: 10$ & $\mathrm{Mn}(\mathrm{II})$ & $1:>200$ \\
\hline $\mathrm{Ru}(\mathrm{IV})$ & $1: 0.25$ & $\mathrm{Al}(\mathrm{III})$ & $1: 8$ & $\mathrm{SiO}_{3}{ }^{2-}$ & $1:>200$ \\
\hline $\operatorname{Ag}(\mathrm{I})$ & $1:<0.1$ & $\mathrm{Ba}(\mathrm{II})$ & $1: 100$ & $\mathrm{~F}^{-}$ & $1:>200$ \\
\hline $\mathrm{Au}(\mathrm{III})$ & $1: 7$ & $\mathrm{Mg}(\mathrm{II}), \mathrm{Ca}(\mathrm{II})$ & $1:>200$ & ЕДТА & $1:>200$ \\
\hline $\mathrm{Hg}(\mathrm{II})$ & $1: 10$ & $\mathrm{~Pb}(\mathrm{II})$ & $1: 75$ & $\mathrm{PO}_{4}^{3-}$ & $1:>200$ \\
\hline $\mathrm{Yb}(\mathrm{III})$ & $1:>200$ & $\mathrm{Cd}(\mathrm{II})$ & $1: 75$ & $\mathrm{C}_{2} \mathrm{O}_{4}{ }^{2-}$ & $1:>200$ \\
\hline $\mathrm{Tb}(\mathrm{III})$ & $1:>200$ & $\mathrm{Zn}(\mathrm{II})$ & $1: 100$ & $\mathrm{Citr}^{3-}$ & $1:>200$ \\
\hline Ho(III) & $1:>200$ & $\mathrm{Ni}(\mathrm{II})$ & $1: 150$ & Tart $^{2-}$ & $1:>200$ \\
\hline Gd(III) & $1:>200$ & $\mathrm{Co}(\mathrm{II})$ & $1: 50$ & $\mathrm{Sal}^{-}$ & $1: 100$ \\
\hline
\end{tabular}

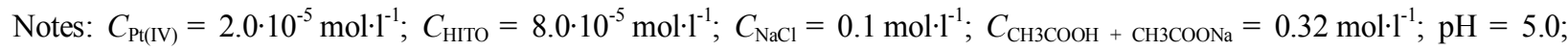
$l=1.0 \mathrm{~cm} ; \lambda=350 \mathrm{~nm}$

Table 4

\section{Permissible excesses of foreign ions during spectrophotometric determination of $\operatorname{Pt}(\mathrm{IV})$ with HITO using masking agents}

\begin{tabular}{|c|c|c|c|c|c|c|}
\hline \multirow{2}{*}{ Ion } & \multirow{2}{*}{ Permissible relations $C_{\mathrm{Pt}(\mathrm{IV})}: C_{\text {ion }}$} & \multicolumn{5}{|c|}{ Masking agent $\left(C_{\mathrm{Pt}(\mathrm{IV})}: C_{\text {ion }}: C_{\text {masking agents }}\right)$} \\
\hline & & EDTA & $\mathrm{Cit}^{3-}$ & $\operatorname{Tart}^{2-}$ & $\mathrm{F}^{-}$ & $\mathrm{PO}_{4}^{3-}$ \\
\hline $\mathrm{Ru}(\mathrm{IV})$ & $1: 0.25$ & $1: 2: 200$ & - & - & - & - \\
\hline $\mathrm{Cu}(\mathrm{II})$ & $1: 0.1$ & $1: 10: 200$ & $1: 15: 200$ & $1: 4: 200$ & - & $1: 5: 200$ \\
\hline $\mathrm{Fe}(\mathrm{III})$ & $1: 0.1$ & $1: 20: 100$ & $1: 10: 100$ & $1: 5: 100$ & $1: 5: 200$ & $1: 10: 100$ \\
\hline $\mathrm{Al}(\mathrm{III})$ & $1: 8$ & - & - & - & $1: 30: 200$ & - \\
\hline
\end{tabular}

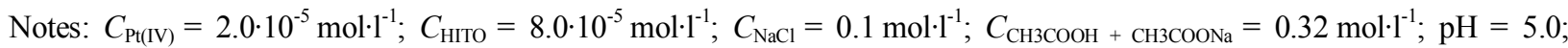
$l=1.0 \mathrm{~cm} ; \lambda=350 \mathrm{~nm}$; sign “_“" means not investigated

Table 5

Spectrophotometric determination of Pt(IV) with HITO in model solutions

\begin{tabular}{|c|c|c|c|c|}
\hline \multirow{2}{*}{ System } & $C_{\mathrm{Pt}}: C_{\text {ion }}$ & \multirow{2}{*}{ Added Pt(IV), $\mu \mathrm{g}$} & Found Pt(IV), $\overline{\mathrm{x}} \pm \frac{\mathrm{S} \cdot \mathrm{t}_{\alpha}}{\sqrt{\mathrm{n}}, \mu \mathrm{g}}$ & $S_{\mathrm{r}}, \%$ \\
\hline Pt-Ru-Co-Ba & $1: 0.16: 30: 100$ & \multirow{2}{*}{98} & $98 \pm 6$ & 2.6 \\
\hline Pt-Ir-Mn-Cd & $1: 0.1: 100: 50$ & & $104 \pm 10$ & 3.9 \\
\hline Pt-Pd-Ni-Pb & $1: 0.1: 75: 50$ & & $102 \pm 8$ & 3.1 \\
\hline
\end{tabular}
$P=0.95$

Notes: $C_{\mathrm{HITO}}=8.0 \cdot 10^{-5} \mathrm{~mol} \cdot 1^{-1} ; C_{\mathrm{NaCl}}=0.1 \mathrm{~mol} \cdot 1^{-1} ; C_{\mathrm{CH} 3 \mathrm{COOH}+\mathrm{CH} 3 \mathrm{COONa}}=0.32 \mathrm{~mol} \cdot 1^{-1} ; \mathrm{pH}=5.0 ; l=1.0 \mathrm{~cm} ; \lambda=350 \mathrm{~nm} ; n=3$;

Table 6

The results of the spectrophotometric determination of platinum in intermetallide $\mathrm{Yb}_{2} \mathrm{Pt}_{2} \mathrm{Ga}_{\text {using }} \mathrm{HITO}$

\begin{tabular}{|c|c|c|c|}
\hline \multirow{2}{*}{ Method of determination } & \multirow{2}{*}{$\omega_{\mathrm{Pt}}^{\text {calc }}, \%$} & $\frac{- \text { real }}{\omega_{\mathrm{Pt}} \pm \frac{\mathrm{S} \cdot \mathrm{t}_{a}}{\sqrt{\mathrm{n}}}, \%}$ & $S_{r}, \%$ \\
\hline Spectrophotometry & 48.4 & $49.9 \pm 3.3$ & 2.7 \\
\hline Voltammetry & $47.6 \pm 2.4$ & 2.0 \\
\hline
\end{tabular}

Notes: $C_{\mathrm{HITO}}=8.0 \cdot 10^{-5} \mathrm{~mol} \cdot 1^{-1} ; C_{\mathrm{NaCl}}=0.1 \mathrm{~mol} \cdot \cdot^{-1} ; C_{\mathrm{CH} 3 \mathrm{COOH}+\mathrm{CH} 3 \mathrm{COONa}}=0.32 \mathrm{~mol} \cdot 1^{-1} ; \mathrm{pH}=5.0 ; l=1.0 \mathrm{~cm} ; \lambda=350 \mathrm{~nm} ; n=3 ;$ $P=0.95$ 
The developed method of the spectrophotometric determination of $\mathrm{Pt}(\mathrm{IV})$ with 5-hydroxyimino-4-imino1,3-thiazolidine-2-one was used during the analysis of the intermetallic tricomponent alloy $\mathrm{Yb}_{2} \mathrm{Pt}_{2} \mathrm{Ga}$. Samples of alloy were synthesized on the inorganic chemistry department of Ivan Franko Lviv National University. The correctness of the results of $\mathrm{Pt}(\mathrm{IV})$ determination in this alloy was verified using voltammetric method for determining platinum for wave reduction $\left(E_{1 / 2}=-0.15 \mathrm{~V}\right)$ from its complex $\left[\mathrm{PtCl}_{6}\right]^{2-}[1,2]$.

The quantities of ytterbium and gallium contained in the alloy did not interfere with the determination of $\mathrm{Pt}(\mathrm{IV})$ with HITO, therefore, there was no masking. The results of $\mathrm{Pt}(\mathrm{IV})$ determination in alloy are presented in Table 6.

As can be seen from the table, the obtained results are well correlated with the values determined by voltammetric method and calculated by atomic percent. The relative standard deviation does not exceed the error of the spectrophotometric methods of analysis.

\section{Conclusions}

It was established that the new derivatives of azolidones PHBS and ITHBA are not suitable for the spectrophotometric determination of $\mathrm{Pt}(\mathrm{IV})$ ions. However, HITO interacts with $\mathrm{Pt}(\mathrm{IV})$ to forms a complex which made it possible to develop a new method for the determination of platinum(IV) ions.

It can be asserted that the developed method based on the reaction of $\mathrm{Pt}(\mathrm{IV})$ with 5-hydroxyimino-4-imino1,3-thiazolidine-2-one is characterized by rather good chemical and analytical characteristics, and also it allows to carry out the determination in less aggressive environments than the known methods. This method can be successfully used for the analysis of platinum in various objects.

\section{References}

[1] Zolotov Yu., Varshal G., Ivanov V.: Analiticheskaia Khimia Metallov Platinovoi Gruppy: Sbornik Obzornykh Statei. Editorial URSS, Moskva 2003.

[2] Ginzburg S., Yezerskaya N., Prokofiev I. et al.: Analiticheskaia Khimia Platinovykh Metallov. Nauka, Moskwa 1972.

[3] Pedersen A., Ulrikkeholm E., Escudero-Escribano M. et al.: Nano Energy, 2016, 29, 249.

https://doi.org/10.1016/j.nanoen.2016.05.026

[4] Georgieva M., Andonovski B.: Anal. Bioanal. Chem., 2003, 375, 836. https://doi.org/10.1007/s00216-003-1783-7

[5] Gur'eva R., Savvin S.: J. Anal. Chem., 2002, 57, 980.

https://doi.org/10.1023/A:1020917221896
[6] Gur'eva R., Savvin S.: Russ. Chem. Rev., 1998, 67, 209. https://doi.org/10.1070/RC1998v067n03ABEH000375

[7] Savvin S., Gur'eva R.: Talanta, 1987, 34, 87.

https://doi.org/10.1016/0039-9140(87)80012-7

[8] Gur'eva R., Savvin S.: Zh. Anal. Kimii, 1995, 50, 1150.

[9] Ostapiuk Yu., Obushak M., Matiychuk et al.: Tetrahedron Lett., 2012, 53, 543. https://doi.org/10.1016/j.tetlet.2011.11.093

[10] Matiichuk V., Potopnyk M., Obushak N.: Russ. J. Org. Chem., 2008, 44, 1352. https://doi.org/10.1134/S1070428008090182

[11] Gorak Yu., Obushak N., Matiichuk V. et al.: Russ. J. Org. Chem., 2009, 45, 541. https://doi.org/10.1134/S1070428009040125 [12] Zelisko N., Atamanyuk D., Ostapiuk Yu. et al.: Tetrahedron, 2015, 71, 9501. https://doi.org/10.1016/j.tet.2015.10.019

[13] Lozynska L., Tymoshuk O.: Chem. Chem. Technol., 2013, 7, 391. https://doi.org/10.23939/chcht07.04.391

[14] Lozyns'ka L., Tymoshuk O., Vrublevs'ka T.: Mater. Sci., 2015, 50, 870. https://doi.org/10.1007/s11003-015-9795-y

[15] Lozynska L., Tymoshuk O., Chaban T.: Acta Chimika

Slovenica, 2015, 62, 159. https://doi.org/10.17344/acsi.2014.866

[16] Tymoshuk O., Fedyshyn O., Oleksiv L. et al.: Visnyk Lviv

Univ. Ser. Chem., 2018, 59, 216.

https://doi.org/10.30970/vch.5901.216

[17] Lozynska L., Tymoshuk O.: Voprosy Khimii i Khimicheskoi

Tekhnologii, 2014, 1, 80.

[18] Lozynska L., Tymoshuk O.: Pat. UA 91160, Publ. Jun. 25, 2014.

[19] Lozynska L., Tymoshuk O.: $3^{\text {rd }}$ International Conference of Young Scientists “CCT-2013”, Ukraine, Lviv 2013, 166.

[20] Tupys A., Kalembkiewicz J., Bazel Y. et al.: J. Mol. Struct., 2017, 1127, 722. https://doi.org/10.1016/j.molstruc.2016.07.119

[21] Bazel Y., Tupys A., Ostapiuk Y. et al.: RSC Adv., 2018, 8, 15940. https://doi.org/10.1039/c8ra02039f

[22] Bazel Y., Tupys A., Ostapiuk Y. et al.: J. Mol. Liq., 2017, 242,

471. https://doi.org/10.1016/j.molliq.2017.07.047

[23] Tupys A., Kalembkiewicz J., Ostapiuk Y. et al.: J. Therm. Anal. Calorim., 2017, 127, 2233. https://doi.org/10.1007/s10973016-5784-0

[24] Fizer M., Sidey V., Tupys A. et al.: J. Mol. Struct., 2017, 1149, 669. https://doi.org/10.1016/j.molstruc.2017.08.037

[25] Tupys A., Tymoshuk O., Rydchuk P.: Chem. Chem.

Technol., 2016, 10, 19. https://doi.org/10.23939/chcht10.01.019

[26] Chaban T., Panchuk R., Klenina O. et al.: Biopolym. Cell,

2012, 28, 389. https://doi.org/10.7124/bc.000075

Received: September 18, 2018 / Revised: October 12, 2018 / Accepted: December 22, 2018

\section{СПЕКТРОФОТОМЕТРИЧНЕ ДОСЛІДЖЕННЯ ВЗАЕМОДІї ПЛАТИНИ(ІV) 3 НОВИМИ ПОХІДНИМИ АЗОЛІДОНІв}

\begin{abstract}
Анотація. Спектрофотометричним методом досліджено взасмодію йонів Pt(IV) з новими похідними азолідонів. Розроблено методику спектрофотометричного визначення платини(IV) за допомогою 5-гідроксиіміно-4-іміно-1,3-тіазолідин-2-ону за рН 5,0 у середовищі ацетатного буферу. Запропонований метод було апробовано під час визначення Pt(IV) у модельних розчинах та металічному сплаві.
\end{abstract}

Ключові слова: спектрофотометрія, платина(IV), азолідони, комплекс. 